\title{
Distribution patterns of sugar industry in eastern Uttar Pradesh, India
}

\author{
Anil Kumar Tiwari ${ }^{1 *}$ and V. N. Sharma ${ }^{2}$ \\ ${ }^{1}$ Kamla Devi Bajoria Degree College, Dubahar, Ballia, Uttar Pradesh, India \\ ${ }^{2}$ Department of Geography, Banaras Hindu University, Varanasi, Uttar Pradesh, India
}

(*Corresponding Author: tiwariani185@gmail.com)

\begin{abstract}
Eastern Uttar Pradesh has a number of mills including large as well as small and ancillaries units because of availability of sufficient amount of sugarcane in this area. It has fertile plain which is highly suitable for cultivation of sugarcane, but many factors related to sugarcane cultivation as well as sugar mills have pushed the sugar industry to be agglomerated at some places which ultimately brought regional variation in distribution patterns and grouped in some clusters. This paper analyses the distribution pattern and clustering of sugar industry in eastern Uttar Pradesh. The study is based on primary as well as secondary data including number of industrial units, capital investment and involved employment. Out of total 30 working mills, 25 mills make clusters occupying eight districts, i.e., Kushinagar, Deoria, Gorakhpur, Mahrajganj and Bahraich, Balrampur, Gonda, Basti. These clusters are located in the Saryupar plain as well as Tarai region which show that sugar industry is exclusively developed in intensive sugarcane production areas.
\end{abstract}

DOI: http://dx.doi.org/10.3126/gjn.v12i1.23417

Keywords: clusters of sugar industry, industrial centre, typology, cluster

\section{Introduction}

Decentralization of industrial activity is an essential requirement for the balanced regional development. Sugar industries automatically follow the decentralization pattern due to scattered cultivation of sugarcane in a region, but variation in socio-economic, 
political and locational factors, the development of sugar industry become lopsided (Tiwari and Sharma, 2013). Therefore, the study of distribution of sugar industry, its relationship with sugarcane production and factors affecting the development of sugar industry is needed to understand for further planning. Sugar industry is the largest organized sector industry in Uttar Pradesh and play very vital role in state economy. The economy in general and rural economy in particular, depends heavily on the progress of sugar industry. More than 2.7 million cultivators and their families are dependent on this industry. It creates employment to over 0.1 million people. In addition, a large number of persons are engaged directly or indirectly on this industry (Singh, 2015). Eastern Uttar Pradesh has made significant strides in sugar production following the development of railway web after 1900 and the emphasis laid on further development of sugar industry started from fourth five year plan (Pandey, 2000). The first large scale sugar factory was established in 1903 and after that many ups and down were faced by this industry. Many problems related to sugarcane cultivation as well as sugar mills are not only reducing the sugarcane production but also weakening the integration between sugarcane production and sugar mills (Singh and Ray, 1975). The tenth and eleventh five year plans were devoted to decentralizing the sugar industry through establishing new factories in backward areas nearer to sugarcane producing areas (Tiwari, 2014). During the last decade, the production of sugarcane has a declining trend due to lacking interest in the sugarcane farming among farmers because of prices instability, lacking consumption of sugarcane in the sugar industries (due to its illness), replacement of sugarcane farms by other cereals cash crops and several other problems related to farmers and industries itself. Out of total 48 sugar mills, 30 sugar mills were established before independence, but, after a Dark-age this industry got renovation and made progress continue (Tiwari, 2017).

Sugar industry basically developed into sugarcane producing areas in eastern Uttar Pradesh, but many other factors are involved in its development. Eastern Uttar Pradesh has a large net sown area (5531019 hectare) (Statistical Diary, 2015), monsoon climate, alluvial soil and high agricultural labourers which create suitable environment for sugarcane cultivation, the only profitable crop in this region. In eastern Uttar Pradesh, the sugar industry is developed mostly in the districts of Saryupar plain which are well connected with railway network. Normally, sugar mills are established nearer to railway stations like, Kaptanganj, Laxmiganj, Ramkola, Padrona, Kathkuiyan, Tamkuhi Road, Khadda and Chhitauni (Kushinagar district), Anandnagar, Ghughuli and Siswa bazaar (Maharajganj district), Pipraich and Sardarnagar (Gorakhpur district), Deoria sadar, 
Bhatni, Gauri bazaar, Baitalpur and Pratappur (Deoria district), Khalilabad (Sant Kabir nagar), Basti sadar, Govind Nagar and Munderwa (Basti), Babhnan and Nawabganj (Gonda), Balrampur and Tulsipur (Balrampur) and Jarwal road (Bahraich). These sugar mills were established under the 'British India Corporation' the outsiders entrepreneurs and at present, many of these are either closed or working under private sectors (Pragati Samiksha, 2014). After independence, development of road transport has minimized transport cost. Besides, old sugar mills were dependent on government power supply, but modern mills have own power plants and they generates power for self use and for sell also (Birru, 2016), therefore, modern sugar mills are developed nearer to sugarcane producing areas. Besides, advancement in cane forming and availability of entrepreneurs are other major factors which have helped in development of sugar industry in eastern Uttar Pradesh. Thus, the establishment of sugar mills in the study area follows the Weberian least cost model in which it is argued that the industry will locate at the weight loosing raw material source because of transportation costs are directly proportional to weight and distance (Mathur and Kalia, 2005). The tendency of sugar mills to locate in sugarcane producing areas has created clusters of sugar mills in eastern Uttar Pradesh. Clusters are a geographically proximate group of interconnected companies and associated institutions in a particular field linked by commonalities and complementarities (Porter, 1998 and Sorvik, 2008). In a cluster, formal and informal relationships exist so that sugar mills can unite forces to deal with suppliers, train their employees, use the same distribution channels, and share information. There is also a high degree of forward and backward cooperation between sugar mills, consumers and suppliers (Duenas, et al., 2007). Present study is an effort to analyse the distribution pattern of sugar industry in the study area.

\section{The study area}

Eastern Uttar Pradesh is extending between $23^{\circ} 51^{\prime} \mathrm{N}$ to $28^{\circ} 31^{\prime} \mathrm{N}$ latitudes and $81^{\circ}$ $30^{\prime} \mathrm{E}$ to $84^{\circ} 39^{\prime} \mathrm{E}$ longitudes, covering an area of $85298.79 \mathrm{~km}^{2}(29.10$ percent of the state) (Figure 1). 


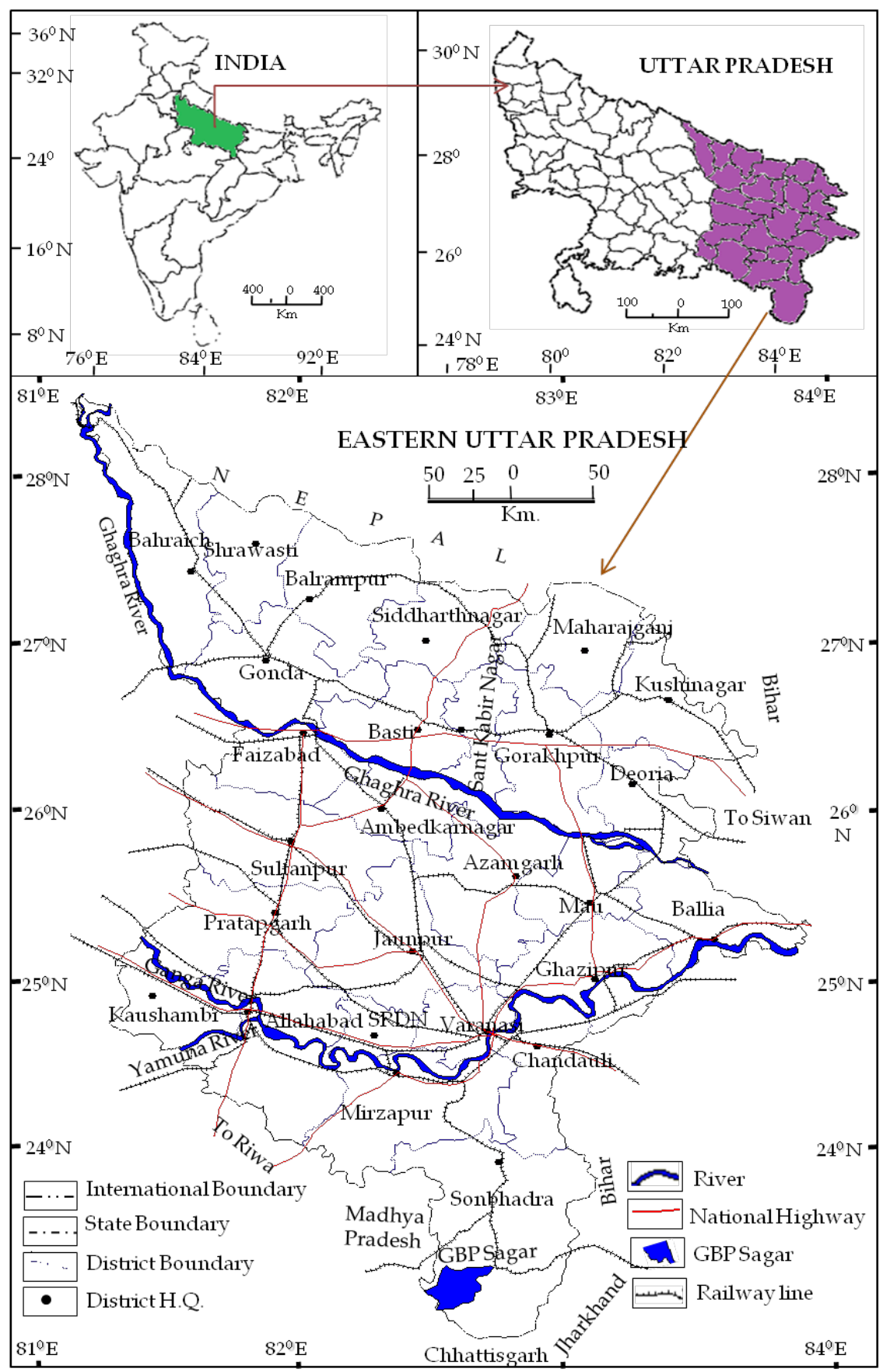

Fig. 2.1

Figure 1: Location and extent of eastern Uttar Pradesh 
Eastern Uttar Pradesh consists of 27 district, 117 tahsil, and 341 community development blocks. It has a fertile alluvial plain deposited by the Ganga, Ghaghra and its tributaries. Agriculture of this region is based on monsoon, but a network of canals also works for irrigation and about 64.94 percent area is irrigated. A number of 88.99 percent populations are engaged in the agriculture in eastern Uttar Pradesh (Census of India, 2011). Alluvial soil, irrigation facility, adequate rainfall, availability of labour etc. are agricultural infrastructure available in this region but adequate raw materials are not available to the agro-based industries due to different problems of agriculture as well as industries. Sugar industry, the only large agro based industry, makes some clusters and these clusters provide large scale employment in surrounding areas. The major objective of the study is to elaborating clusters of sugar industry in eastern Uttar Pradesh.

\section{Data sources and methodology}

The study is based on both the primary and secondary data. Data collection and analysis methods and sources are as below:

1. Primary data have been collected during industrial survey of sugar industries in 201314. There were total 48 sugar mills in the study area in which 30 units in running condition and 18 were sick units. In this industrial survey, total 48 sugar mills (both working and sick) were surveyed regarding their capital investment, employment, production, by-production and raw materials with the help of Interview Schedules.

2. Secondary data have been obtained from the governmental and non-governmental sources basically from Directorate of industries, Uttar Pradesh, Kanpur and Udyog Bandhu, Lucknow.

3. Identification of the industrial clusters has been based on index of concentration. Concentration of industries is calculated as 'ratio of sugar mills with the total area of the district' (number of mills $\div$ total area) (Ren, Wen and Ren, 2014). It indicates areal proximity of mills.

4. Percentage calculation, tables and Spearmans's rank correlation to show relationship between availability of raw material and establishment of sugar mills have been calculated with the help of MS excel workbook and PAST (Paleontological Statistics) Version - 2.14 Software. Maps have been drawn on ArcGIS 10.4 software.

\section{Result and discussion}

\section{Distribution patterns of sugar industries}

The analysis of distribution of sugar industry has been studied in two parts, i.e., 1) typology of sugar industry in terms of number of unit, capital investment and employment and, 2) locational distribution of industries in order to grasp the spatial patterns of grouping of sugar mills through the analysis of industrial clusters. 


\section{Typology of sugar industry}

Broadly, the structure of sugar industry in the eastern Uttar Pradesh may be divided into the heavy, small sugar units and ancillary units (Tiwari, 2017). There is a larger number of factory-employment in heavy sugar mills followed by small sugar mills (registered) and ancillary units. In all about 20203 persons were engaged in heavy (17743 persons, 87.82 percent) and small sugar units (246 persons, 12.18 percent) in 2015.

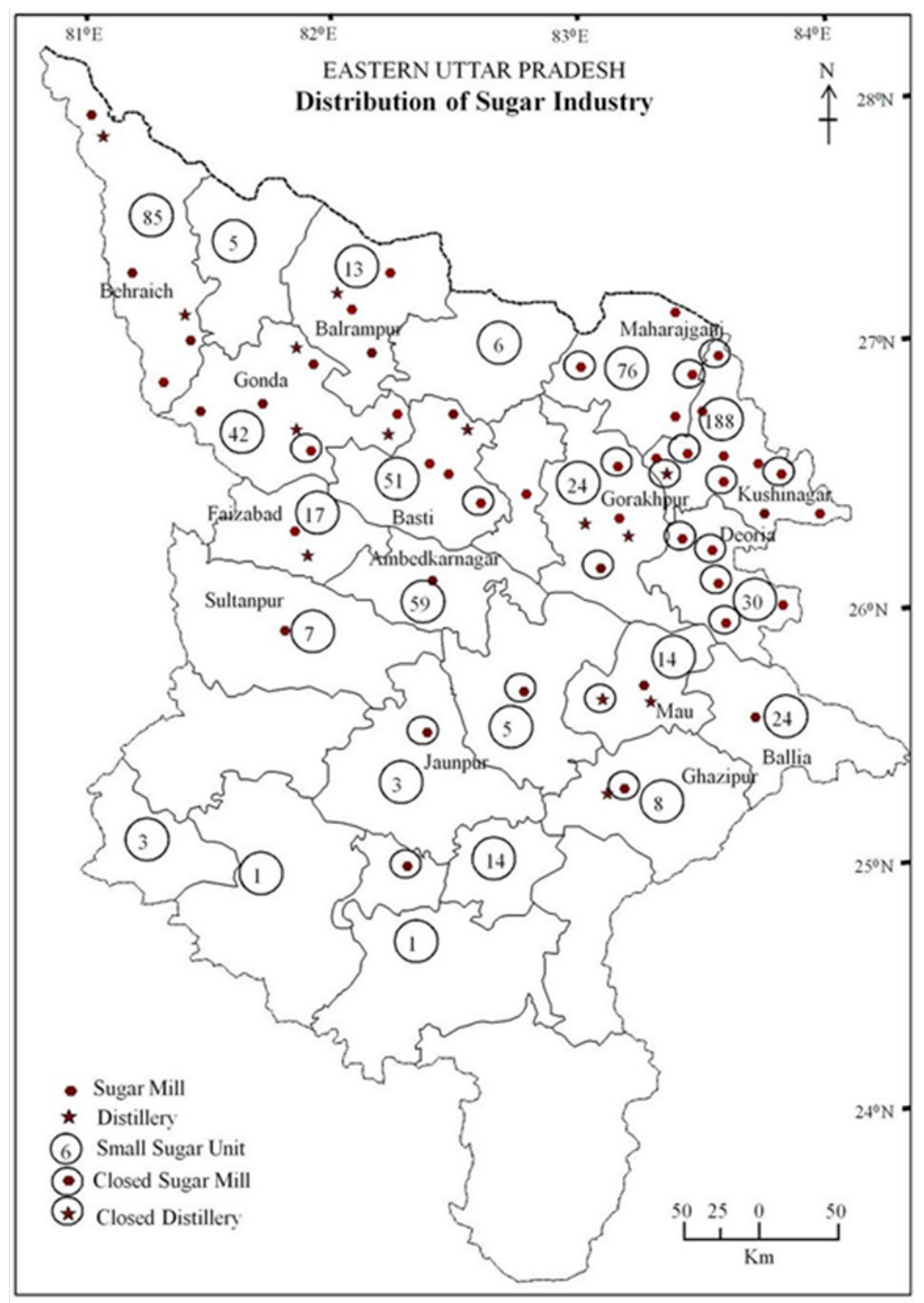

Figure 2: Distribution of sugar mills and distilleries 
In eastern Uttar Pradesh, there were 30 (95000 million capital investment) heavy sugar units and 776 (capital investment 55.64 million) small sugar units. In fact, the heavy sugar mills constitute the staple economic activities of the study area. The total number of major/medium working sugar factories were 30 (Figure 2) with a capital investment of 95000 million and employment of 17743 persons in 2015.

The major prerogative sugar factories were established at Pratappur (Deoria), Hata, Ramkola, Tamkuhi Road, Kaptanganj (Kushinagar), Sardarnagar (Gorakhpur), Khalilabad (Sant Kabir Nagar), Basti, Walterganj and Rudauli (Basti), Mankapur, Babhnan, Kundurakhi and Maizapr (Gonda), Balrampur, Tulsipur and Itaimaida (Balrampur), Chilwaria, Kaisarganj, Jarwal Road and Nanpara (Bahraich), Motinagar Masaudha (Faizabad), Mijhaura (Ambedkarnagar), Ghosi (Mau) and Sultanpur. Development of sugar industry in regard with heavy factories had been rapid between from 1903 to 1943, 1969 to 1988 (Pandey, 2000) and after 2004. About 30 units were already established before independence. Further, during two and half decades (194369), there were no new unit established in this area. However, after 1969 development of sugar industry were restarted and in 2012, it were 48 major and medium sugar units but about 18 units were sick. Only distilleries are developed as an ancillary of sugar industry in eastern Uttar Pradesh. The total number of distillery was 14 (in which 2 units is sick) with a capital investment of Rs. 8053.8 million and employment of 2304 persons. The major distillery are established at Gorakhpur Industrial Development Authority (GIDA) and Sardarnagar (Gorakhpur), Rudauli (Basti), Mankapur, Nawabganj and Babhnan (Gonda), Balrampur, Chilwaria and Nanpara (Bahraich), Masaudha (Faizabad), Ghosi (Mau) and Nandganj (Ghazipur). Development of distilleries has been rapid after impendence. Only one unit was established at Kaptanganj before independence. Further, during four decades (1951-92), there were no new unit was established here. However, after 1992 development of distilleries was restarted and upto 2012, it were 14 units, but, now two units are facing the problem of sickness. Most of distilleries in this region were established by sugar mills, only Kaptanganj, Nawabganj, Nandganj and India Glycols, GIDA were established independently. Besides, Cane-crusher and kolhu are developed as small scale and cottage industries in eastern Uttar Pradesh, which are making Gur or Bheli (Jaggery), Rab and Khandsari for local demands. At the end of 2012, total number of registered small/cottage sugar units was 671 with capital investment of Rs. 55.64 million and employment of 2460 persons (Table 1). Besides, a number of crushers and Kolhus are working without registration. Before independence, only 11 units were registered and after independence, it is increasing regularly. At the end of 2012, Kushinagar had the highest number of small scale registered sugar units (188 units, 27.81 percent of the region) followed by Bahraich ( 85 units, 12.57 percent), Maharajganj (76 units, 11.24 percent), Ambedkarnagar (59 units, 8.73 percent) and Basti (51 units, 7.54 percent) while Sant Kabir Nagar, Chandauli, Sonbhadra, Sant Ravidas Nagar and Pratapgarh had no any small scale registered sugar unit. 
Sugar factories are mostly centralised in the Saryupar plain. As for as the distribution of heavy sugar factories is concerned, 20 percent sugar units were located in Kushinagar district followed by Bahraich (13.33 percent), Gonda (13.33 percent), Balrampur (10 percent), Basti (10 percent), Maharajganj (6.67 percent) and Ambedkarnagar, Ballia, Deoria, Faizabad, Gorakhpur, Mau, Sant Kabir Nagar and Sultanpur (having the 3.33 percent of total units) in 2012. Thus, all the clusters of sugar industry were emerged and developed around these centres. The remaining districts had not any large scale sugar mill except distilleries as ancillary of sugar industry. Gonda district had 25 percent of total distillery units followed by Bahraich and Gorakhpur (16 percent), and Balrampur, Basti, Faizabad, Mau and Ghazipur (having the 8.33 percent each).

Table 1: Distribution patterns of sugar industry

\begin{tabular}{|c|c|c|c|c|c|c|c|c|c|}
\hline \multirow{2}{*}{ Districts } & \multicolumn{3}{|c|}{ Percentage of Units } & \multicolumn{3}{|c|}{ Percentage of Employment } & \multicolumn{3}{|c|}{$\begin{array}{c}\text { Percentage of Capital } \\
\text { Investment }\end{array}$} \\
\hline & $\begin{array}{l}\text { Sugar } \\
\text { Mills }\end{array}$ & Ancillaries & $\begin{array}{l}\text { Small } \\
\text { units }\end{array}$ & $\begin{array}{l}\text { Sugar } \\
\text { Mills }\end{array}$ & Ancillaries & $\begin{array}{c}\text { Small } \\
\text { units }\end{array}$ & $\begin{array}{l}\text { Sugar } \\
\text { Mills } \\
\end{array}$ & Ancillaries & $\begin{array}{l}\text { Small } \\
\text { units }\end{array}$ \\
\hline Kushinagar & 20.00 & ---- & 27.81 & 18.97 & ---- & 28.58 & 18.95 & $\begin{array}{ll}--- \\
\end{array}$ & 23.70 \\
\hline Bahraich & 13.33 & 16.67 & 12.57 & 16.13 & 7.47 & 12.80 & 10.53 & 11.83 & 24.87 \\
\hline Mahrajganj & 6.67 & ---- & 11.24 & 4.19 & ---- & 9.84 & 4.84 & ---- & 6.92 \\
\hline Ambedkarnagar & 3.33 & $\begin{array}{ll}--- \\
\end{array}$ & 8.73 & 5.65 & $\begin{array}{c}--- \\
\end{array}$ & 9.07 & 2.95 & \begin{tabular}{l|l}
--- \\
\end{tabular} & 7.16 \\
\hline S. Kabir Nagar & 3.33 & ---- & +--- & 2.48 & +--- & ---- & 3.16 & \begin{tabular}{ll|}
--- \\
\end{tabular} & ---- \\
\hline Basti & 10.00 & 8.33 & 7.54 & 6.97 & 3.21 & 6.71 & 8.42 & 8.72 & 4.85 \\
\hline Gonda & 13.33 & 25.00 & 6.21 & 12.96 & 16.22 & 6.59 & 15.37 & 28.41 & 3.99 \\
\hline Deoria & 3.33 & ---- & 4.44 & 2.24 & ---- & 3.33 & 4.21 & --- & 2.06 \\
\hline Gorakhpur & 3.33 & 16.67 & 3.55 & 4.76 & 53.76 & 3.82 & 4.21 & 39.84 & 1.35 \\
\hline Ballia & 3.33 & ---- & 3.55 & 2.84 & ---- & 3.58 & 1.58 & --- & 1.85 \\
\hline Faizabad & 3.33 & 8.33 & 2.51 & 3.11 & 3.21 & 2.85 & 4.21 & 1.87 & 3.54 \\
\hline Varanasi & ---- & $\begin{array}{ll}---- \\
\end{array}$ & 2.07 & ---- & $\begin{array}{ll}--- \\
\end{array}$ & 1.87 & $\begin{array}{ll}--- \\
\end{array}$ & ---- & 0.92 \\
\hline Mau & 3.33 & 8.33 & 2.07 & 3.81 & 5.82 & 1.83 & 3.16 & 1.25 & 8.98 \\
\hline Balrampur & 10.00 & 8.33 & 1.92 & 12.93 & 6.19 & 2.20 & 15.26 & 1.87 & 1.33 \\
\hline Ghazipur & ---- & 8.33 & 1.18 & ---- & 4.12 & 1.14 & ---- & 6.23 & 0.22 \\
\hline Sultanpur & 3.33 & ---- & 1.04 & 2.95 & ---- & 0.73 & 3.16 & ---- & 0.69 \\
\hline Siddharthnagar & ---- & $\begin{array}{ll}--- \\
\end{array}$ & 0.89 & ---- & $\begin{array}{ll}--- \\
\end{array}$ & 2.11 & $\begin{array}{ll}--- \\
\end{array}$ & $\begin{array}{ll}--- \\
\end{array}$ & 0.80 \\
\hline Shrawasti & --- & --- & 0.74 & --- & --- & 0.65 & --- & $\begin{array}{ll}--- \\
\end{array}$ & 0.17 \\
\hline Azamgarh & ---- & --- & 0.74 & ---- & --- & 1.22 & --- & \begin{tabular}{l|}
--- \\
\end{tabular} & 2.75 \\
\hline Jaunpur & ---- & ---- & 0.44 & --- & --- & 0.37 & ---- & ---- & 0.08 \\
\hline Kaushambi & $\begin{array}{ll}--- \\
\end{array}$ & $\begin{array}{l}--- \\
\end{array}$ & 0.44 & $\begin{array}{ll}--- \\
\end{array}$ & $\begin{array}{l}--- \\
\end{array}$ & 0.49 & ---- & ---- & 3.64 \\
\hline Mirzapur & $\begin{array}{ll}--- \\
\end{array}$ & ---- & 0.15 & $\begin{array}{ll}--- \\
\end{array}$ & ---- & 0.12 & ---- & \begin{tabular}{ll|}
--- \\
-1
\end{tabular} & 0.03 \\
\hline Allahabad & ---- & ---- & 0.15 & \begin{tabular}{l|l}
--- \\
\end{tabular} & ---- & 0.12 & ---- & ---- & 0.08 \\
\hline
\end{tabular}

Source: Field Survey, 2013-14 \& Pragati Samiksha, 2014 
Besides, small scale (registered) sugar units (Crushers and Kolhus) were developed in about all districts of eastern Uttar Pradesh. Kushinagar district have 27.81 percent of total small units followed by Bahraich (12.57 percent), Mahrajganj (11.24 percent), Ambedkarnagar (8.73 percent), Basti (7.54 percent), Gonda (6.21 percent), Deoria (4.44 percent), Gorakhpur and Ballia (3.55 percent), Faizabad (2.51 percent), Varanasi and Mau (2.07 percent), Balrampur (1.92 percent), Ghazipur (1.18 percent), Sultanpur (1.04 percent) and Siddharthnagar, Shrawasti, Azamgarh, Jaunpur, Kaushambi, Mirzapur and Allahabad (each had less than 1 percent of total small units). Sant Kabir Nagar, Sant Ravidas Nagar, Pratapgarh, Sonbhadra and Chandauli have not any small scale registered sugar units (Table 1). The distribution pattern of employment in sugar industry brings out an unbalanced regional distribution scenario in the study area. It presents a clear picture of the degree of development of sugar industry in different districts of the eastern Uttar Pradesh. Kushinagar district (18.97 percent) provided the maximum percentage of total employment engaged in sugar mills followed by Bahraich (16.13 percent), Gonda (12.96 percent), Balrampur (12.93 percent), Basti (6.97 percent), Ambedkarnagar (5.65 percent), Gorakhpur (4.76 percent), Mahrajganj (4.19 percent) and Faizabad (3.11 percent) in 2012. Rest of the districts (Ballia, Deoria, Mau, Sant Kabir Nagar and Sultanpur) had less than 2 percent of the total employment in sugar mills. In considering distilleries, Gorakhpur (53.76 percent) employed the maximum percentage of total employment followed by Gonda (16.22 percent), Bahraich (7.47 percent) which Balrampur (95.82 percent) and Mau, Ghazipur, Basti and Faizabad had less than 5 percent of employment in distilleries.

In the small scale sector, Kushinagar had the highest percentage of employment (28.58 percent) followed by Bahraich (12.8 percent), Mahrajganj (9.84 percent), Ambedkarnagar (9.07 percent), Basti (6.71 percent), Gonda (6.59 percent), Gorakhpur (3.82 percent), Ballia (3.58 percent) and Deoria (3.33 percent), Faizabad, Varanasi, Mau, Balrampur, Ghazipur, Sultanpur, Siddharthnagar, Shrawasti, Azamgarh, Jaunpur, Kaushambi, Mirzapur and Allahabad (each had less than 2 percent of total employment in small units) in 2012. Major part of the capital had been invested mostly in four districts, i.e., Kushinagar (18.95 percent), Gonda (15.37 percent), Balrampur (15.26 percent) and Bahraich (10.53 percent) in 2012 followed by Basti (8.42 percent) and Mahrajganj (4.84 percent) while Deoria, Gorakhpur, Faizabad, Sant Kabir Nagar, Sultanpur, Ambedkarnagar, Ballia and Mau had less than 4 percent capital investment. In distilleries, Gorakhpur district (39.84 percent) had the highest capital investment followed by Gonda (28.41 percent), Bahraich (11.83 percent), Basti (8.72 percent) and Ghazipur (6.23 percent) Balrampur, Faizabad and Mau had less than 2 percent of capital investment. The investment pattern in the small scale sugar units is quite different (Table 1). Bahraich had the highest percentage (24.9 percent) followed by Kushinagar (23.7 
percent), Mau (8.98 percent), Ambedkarnagar (7.16 percent), Mahrajganj (6.92 percent), Basti (4.85 percent), Gonda (3.99 percent), Kaushambi (3.64 percent), Faizabad (3.54 percent), Azamgarh (2.75 percent) and Deoria (2.06 percent) while remaining district have less than 2 percent of capital investment. Eight districts out of twenty seven in eastern Uttar Pradesh have no any sugar or ancillary industry (except small units). These districts are Varanasi, Siddharthnagar, Shrawasti, Azamgarh, Jaunpur, Kaushambi, Mirzapur and Allahabad (Table 1). These districts produce sugarcane and have the potentials of development of the sugar industry.

Sugar industry uses grass product (sugarcane) as raw material which follows the Weber's theory for its establishment near the source of sugarcane production. According to Spearman's Rank method, correlation coefficient between cane production and number of sugar units is 0.69322 which shows good association between production of sugarcane and number of sugar mills (Table 2).

Table 2: Sugarcane production and number of sugar units (Heavy + Small Units)

(Spearman's Rank Table)

\begin{tabular}{|l|r|r|r|r|}
\hline \multicolumn{1}{|c|}{ Districts } & $\begin{array}{c}\text { Production of cane } \\
\text { (ton) }\end{array}$ & Rank & $\begin{array}{c}\text { Number of Sugar } \\
\text { unit }\end{array}$ & Rank \\
\hline Kushinagar & 3410665 & 1 & 194 & 1 \\
\hline Bahraich & 989375 & 5 & 91 & 2 \\
\hline Maharajganj & 931756 & 7 & 78 & 3 \\
\hline Ambedkar Nagar & 532717 & 9 & 60 & 4 \\
\hline Basti & 1630888 & 4 & 55 & 5 \\
\hline Gonda & 2476872 & 2 & 49 & 6 \\
\hline Deoria & 448363 & 12 & 31 & 7 \\
\hline Gorakhpur & 146519 & 19 & 27 & 8 \\
\hline Ballia & 243032 & 16 & 25 & 9 \\
\hline Faizabad & 943938 & 6 & 19 & 10 \\
\hline Balrampur & 2106596 & 3 & 17 & 11 \\
\hline Mau & 286239 & 14 & 16 & 12 \\
\hline Varanasi & 181696 & 17 & 14 & 13 \\
\hline Ghazipur & 268371 & 15 & 9 & 14 \\
\hline Sultanpur & 480355 & 11 & 8 & 15 \\
\hline Siddhartha Nagar & 118620 & 20 & 6 & 16 \\
\hline Azamgarh & 838358 & 8 & 5 & 17.5 \\
\hline Sharawasti & 316756 & 13 & 5 & 17.5 \\
\hline Jaunpur & 526298 & 10 & 3 & 19.5 \\
\hline Kaushambi & 78519 & 22 & 3 & 19.5 \\
\hline Sant Kabir Nagar & 173575 & 18 & 1 & 22 \\
\hline Mirzapur & 90454 & 21 & 1 & 22 \\
\hline Allahabad & 40837 & 23 & 1 & 22 \\
\hline Source: & & & &
\end{tabular}

Source: Statistical diary, 2015 
Significance level of correlation coefficient on the basis of Student T-Test is 4.40 which is higher than tabulated value up to 99 percent level of significance (2.82). Hence, there is positive correlation between number of sugar mills and sugarcane production. High sugarcane producing districts have high number of sugar mills. For example, Kushinagar district had the highest sugarcane production (3410.67 thousand ton) and the highest sugar units (194) while Sonbhadra has the lowest sugarcane production (9.38 thousand ton) and no any sugar unit. Thus, production of sugarcane is playing dominant role in development of sugar industries. In other words, 'Distribution pattern of sugar industry follows the availability of raw materials (Sugarcane production)' as propounded in Weber's theory of industrial location. According to Weber's theory, localised raw materials attract the industries to be located near source due to enhancement in transportation cost. The result of this study shows matching trend with Weber's theory.

\section{Industrial clusters}

Eastern Uttar Pradesh has to fill up a large gap of development of sugar industry. Many districts have no any sugar mills. The concentration and continuous establishment of sugar mills are attracted to limited centres which have resources and infrastructures and they may be identified as 'industrial clusters of sugar industry'. According to the index of concentration of industries, district of Saryupar plain have the highest value, i.e., Kushinagr (0.667), Bahraich (0.208), Mahrajganj (0.268), Basti (0.198), Gonda (0.122), Deoria (0.124), Sant Kabir Nagar (0.006) and Gorakhpur (0.081). Besides, these adjoining districts have heavy sugar mills with heavy investment, production capacity and employment generation. Along with the proximity of sugar mills, the number of units and employment has been considered to explain the industrial clusters of sugar industry.

Table 3: Structure of clusters of sugar industry

\begin{tabular}{|l|r|r|r|r|r|r|}
\hline \multirow{2}{*}{ Districts } & \multicolumn{3}{|c|}{ Units (Percent) } & \multicolumn{2}{c|}{ Employment (Percent) } \\
\cline { 2 - 7 } & $\begin{array}{c}\text { Sugar } \\
\text { mills }\end{array}$ & Distilleries & $\begin{array}{c}\text { Small } \\
\text { scale }\end{array}$ & $\begin{array}{c}\text { Sugar } \\
\text { mills }\end{array}$ & Distilleries & $\begin{array}{c}\text { Small } \\
\text { scale }\end{array}$ \\
\hline $\begin{array}{l}\text { Kushinagar-Deoria- } \\
\text { Gorakhpur-Maharajganj }\end{array}$ & 33.33 & 16.67 & 47.04 & 28.54 & 53.76 & 45.57 \\
\hline Bahraich & 13.33 & 16.67 & 12.57 & 16.13 & 14.44 & 6.63 \\
\hline Basti-Khalilabad & 13.33 & 8.33 & 7.54 & 9.32 & 3.21 & 6.71 \\
\hline Gonda-Balrampur & 23.33 & 33.33 & 8.14 & 27.11 & 22.41 & 8.78 \\
\hline Total & 83.32 & 75.00 & 75.29 & 81.10 & 93.82 & 67.69 \\
\hline
\end{tabular}

Source: Directory of industries, 2014

One major cluster (Kushinagar-Deoria-Gorakhpur-Maharajganj) (Figure 3) and three minor clusters (Figure 4) namely, (A) Bahraich, (B) Basti-Khalilabad and (C) Gonda- 
Balrampur clusters are identified. These clusters had 83.32 percent unit and 81.10 percent of employment of sugar mills, 75 percent units and 93.82 percent of employment of distilleries, 75.29 percent units and 67.69 percent of employment of small scale sugar units (Table 3) in 2012. Besides, many small centres of sugar industry also exist in eastern Uttar Pradesh, like, Faizabad, Sultanpur, Ambedkarnagar, Ballia and Ghazipur etc. The identification and spatial industrial structure of sugar industry of these clusters have been analysed in detail.

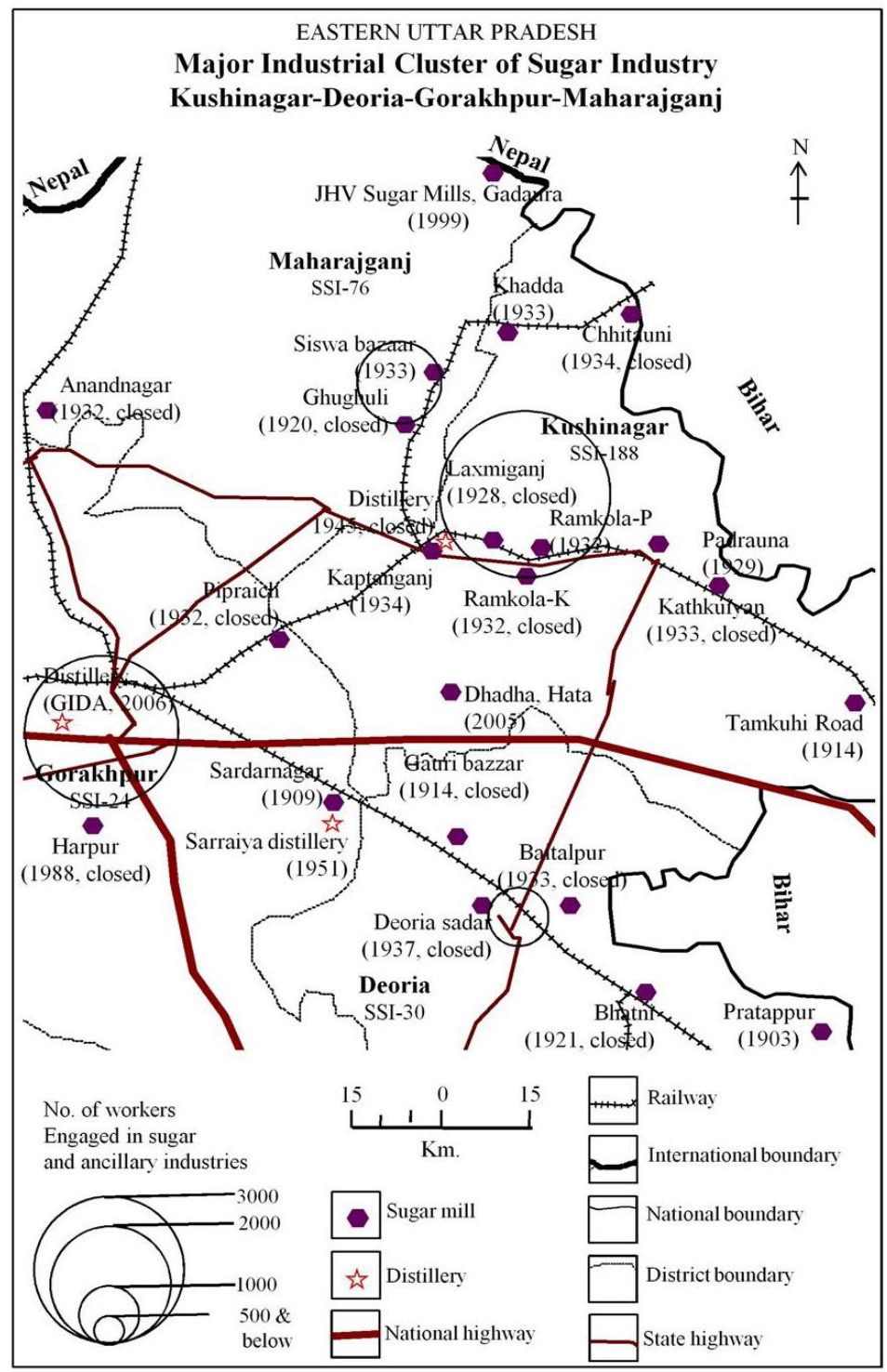

Figure 3: Kushinagar - Deoria - Gorakhpur - Maharajganj industrial cluster 


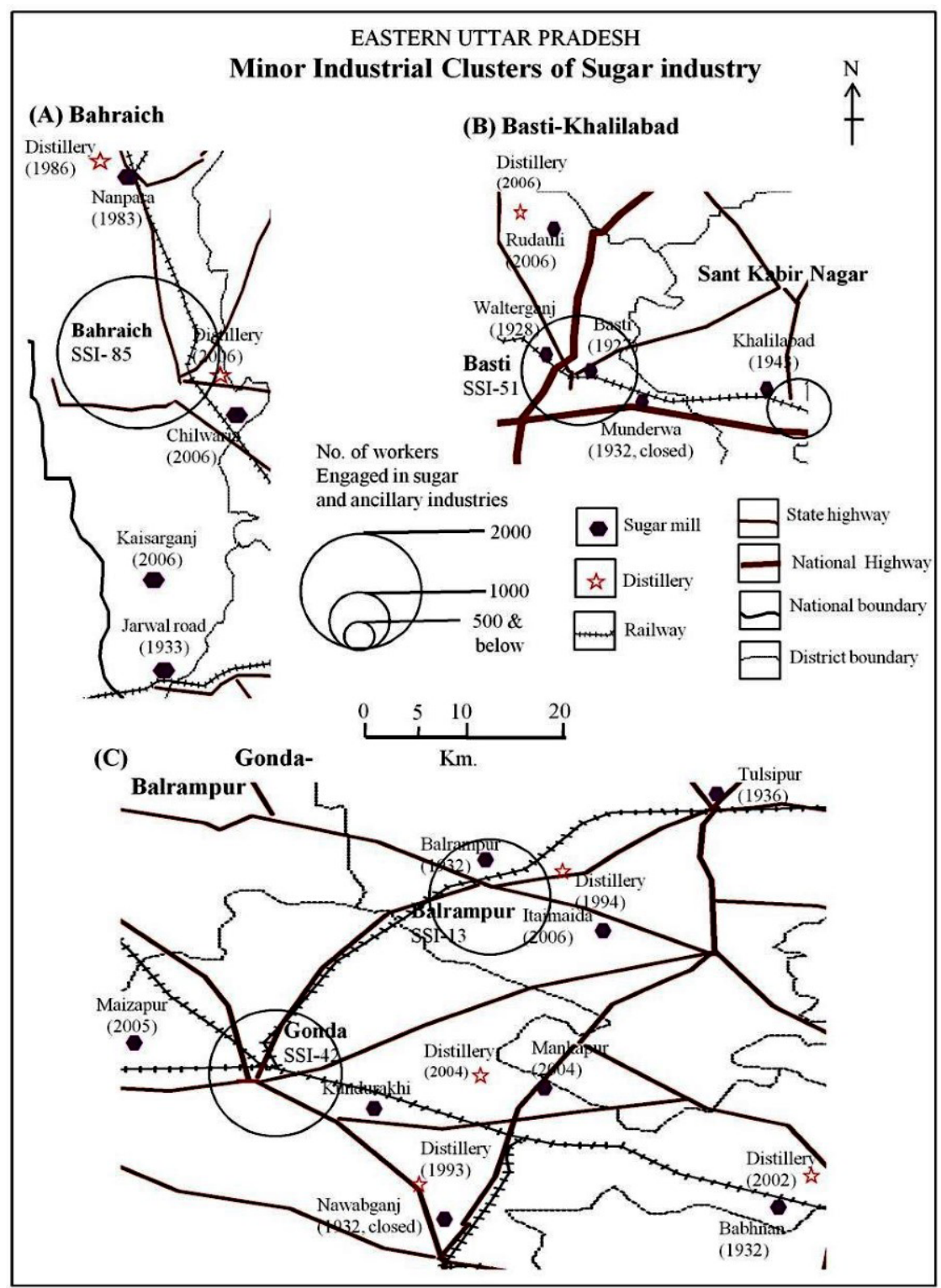

Figure 4: Minor industrial clusters

\section{Major cluster}

\section{Kushinagar-Deoria-Gorakhpur-Mahrajganj cluster}

It is the largest and the most significant sugar industry agglomeration which lies in the north eastern part (Tarai) of the eastern Uttar Pradesh forming an alignment 
on Kaptanganj, Ramkola, Siswa bazaar, Khadda, Ramkola, Tamkuhi road, Hata, Sardarnagar, Pratappur, Gadaura and Gorakhpur centres. It accounted 33.33 percent of total units and 36.79 percent of total employment of sugar mills, 16.67 Percent of units and 53.76 percent of employment of total distilleries and 47.04 percent of units and 45.57 percent employment of total small units (Table 4 and Figure 2) in 2012.

Table 4: Structure of Kushinagar-Deoria-Gorakhpur-Mahrajganj cluster

\begin{tabular}{|l|r|r|r|r|r|r|r|r|r|r|r|r|}
\hline \multirow{3}{*}{ Districts } & \multicolumn{8}{|c|}{ No. of units and its percentage of total units } & \multicolumn{7}{|c|}{ Employment and its percentage of total } \\
& \multicolumn{1}{|c|}{$\begin{array}{c}\text { Sugar } \\
\text { mills }\end{array}$} & $\begin{array}{c}\text { Per } \\
\text { cent }\end{array}$ & $\begin{array}{c}\text { Disti } \\
\text { llery }\end{array}$ & $\begin{array}{c}\text { Per } \\
\text { cent }\end{array}$ & $\begin{array}{c}\text { Small } \\
\text { scale }\end{array}$ & $\begin{array}{c}\text { Per } \\
\text { cent }\end{array}$ & $\begin{array}{c}\text { Sugar } \\
\text { mills }\end{array}$ & $\begin{array}{c}\text { Per } \\
\text { cent }\end{array}$ & $\begin{array}{c}\text { Disti } \\
\text { llery }\end{array}$ & $\begin{array}{c}\text { Per } \\
\text { cent }\end{array}$ & $\begin{array}{c}\text { Small } \\
\text { scale }\end{array}$ & $\begin{array}{c}\text { Per } \\
\text { cent }\end{array}$ \\
\hline Kushinagar & 6 & 20.00 & 0 & 0 & 188 & 27.81 & 3360 & 17.95 & 0 & 0 & 703 & 28.58 \\
\hline Deoria & 1 & 3.33 & 0 & 0 & 30 & 4.44 & 396 & 2.12 & 0 & 0 & 82 & 3.33 \\
\hline Gorakhpur & 1 & 3.33 & 2 & 16.67 & 24 & 3.55 & 844 & 4.51 & 1173 & 53.76 & 94 & 3.82 \\
\hline Mahrajganj & 2 & 6.67 & 0 & 0 & 76 & 11.24 & 743 & 3.97 & 0 & 0 & 242 & 9.84 \\
\hline Total & 10 & 33.33 & 2 & 16.67 & 318 & 47.04 & 5343 & 28.54 & 1173 & 53.76 & 1121 & 45.57 \\
\hline
\end{tabular}

Source: Directory of industries, 2014

Availability of transportation (especially railway), labour, power and high production of sugarcane inspired the growth of sugar industry in this cluster. Kushinagar had the highest sugar mills in the eastern Uttar Pradesh registering ( 6 units, 20 percent) followed by Mahrajganj ( 2 units, 6.67 Percent), Gorakhpur and Deoria (each of 1 units). Most of the units (9) were established before independence. First sugar mill of India was also established in this cluster at Pratappur (Deoria) in 1903. Only two distilleries were established here in Gorakhpur district, first Sarraiya Distillery at Sardarnagar in 1951 and, second, India Glycols Limited at GIDA in 2005. Besides, small scale sugar units are also developed as cottage industry in the villages of this cluster. Kushinagar had highest number of small units (188 units, 27.81 percent) followed by Mahrajganj (76 units, 11.24 percent), Deoria (30 units, 4.44 percent) and Gorakhpur ( 24 units, 3.55 percent). In this cluster sugar mills provided total employment of 5343 persons ( 36.79 percent), in which Kushinagar had highest employment in sugar mills (3360 persons, 17.95 percent) followed by Gorakhpur (844 persons, 4.51 percent), Mahrajganj (743 persons, 3.97 percent) and Deoria (396 persons, 2.12 percent) while Gorakhpur provided employment to 1173 persons which was 53.76 percent of eastern Uttar Pradesh. Employment in distillery in Gorakhpur district was 1173 persons (53.76 percent) in eastern Uttar Pradesh. The highest employment in small scale sugar units was found in Kushinagar (703 persons, 28.58 percent) followed by Mahrajganj (242 persons, 9.84 percent), Gorakhpur (94 persons, 3.82 percent) and Deoria (82 persons, 3.33 percent). Sarraiya Sugar Mill Ltd., Sardarnagar (Gorakhpur), The Kanoria Sugar and General Manufacturing Company Ltd., Kaptanganj, Triveni Engineering \& Industries Ltd. (P), Ramkola, J.H.V. Distillery and 
Sugar Mills Ltd., Padrauna, IPL Ltd. (Sugar \& Chemicals), Khadda, U.P. State Sugar Corporation Ltd., Tamkuhi Road and New India Sugar Mills, Dhadha Bujurg, Hata (Kushinagar), The Bajaj Hindusthan Sugar Industries Limited, Pratappur (Pratappur Sugar Mill, Deoria), J.H.V. sugar mills Ltd., Gadaura and JHV sugar and chemicals (Siswa bazaar) are the major working sugar mills in this cluster. Besides, 12 sugar mills of this cluster are closed, i.e., U.P. State Sugar Corporation Limited, Pipraich and Dhuriyapar Kisan Sahkari Chini Mill Ltd., Harpur (Gorakhpur), 'Cawnpore Sugar Works Ltd., Gauri bazaar', Dynamic Sugar Pvt. Ltd., Baitalpur, U.P. State Sugar Corporation Limited, Bhatni and Deoria sadar (Deoria), Ganesh Sugar Mills, Anandnagar and Zircon Sugar Solution, Ghughuli (Mahrajganj) while a distillery, namely, 'Kaptanganj Distillery Limited' is facing sickness due to management problems.

\section{Minor clusters}

Bahraich cluster: The cluster is located in the north western part as well as Tarai region of the eastern Uttar Pradesh in Bahraich district. This cluster registered 13.33 percent of total units and 16.13 percent of total employment of sugar mills, 16.67 percent of units and 14.44 percent of employment of total distilleries and 12.57 percent of units and 6.63 percent employment of total small units (Table 5) in 2012. Availability of road transportation and railway, labour, power and high production of sugarcane attract the establishment of sugar industry in this cluster (Figure 4). Bahraich had 4 sugar mills, 2 distilleries and 85 small scale sugar units (Table 5).

Table 5: Structure of minor clusters

\begin{tabular}{|c|c|c|c|c|c|c|c|c|c|c|c|c|}
\hline \multirow[b]{2}{*}{ Districts } & \multicolumn{6}{|c|}{ No. of units and its percentage of total units } & \multicolumn{6}{|c|}{$\begin{array}{c}\text { Employment and its percentage of total } \\
\text { employment }\end{array}$} \\
\hline & 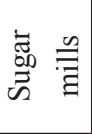 & 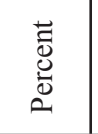 & 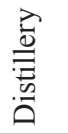 & 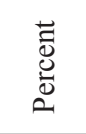 & 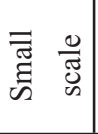 & 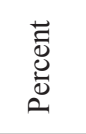 & 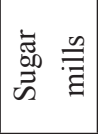 & $\begin{array}{l}\overrightarrow{0} \\
\stackrel{0}{0} \\
\stackrel{0}{0}\end{array}$ & 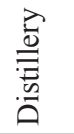 & 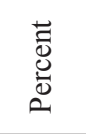 & 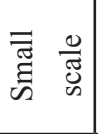 & 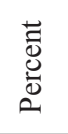 \\
\hline \multicolumn{13}{|c|}{ Bahraich Cluster } \\
\hline Bahraich & 4 & 13.33 & 2 & 16.67 & 85 & 12.57 & 3020 & 16.13 & 315 & 14.44 & 163 & 6.63 \\
\hline \multicolumn{13}{|c|}{ Basti-Khalilabad Cluster } \\
\hline Basti & 3 & 10.00 & 1 & 8.33 & 51 & 7.54 & 1305 & 6.97 & 70 & 3.21 & 165 & 6.71 \\
\hline Khalili & 1 & & 0 & 0.0 & 0 & 0.00 & 440 & 2.35 & 0 & 0.00 & 0 & 0.00 \\
\hline Total & 4 & 13.33 & 1 & 8.33 & 51 & 7.54 & 1745 & 9.32 & 70 & 3.21 & 165 & 6.71 \\
\hline \multicolumn{13}{|c|}{ Gonda-Balrampur Cluster } \\
\hline Gonda & 4 & 13.33 & 3 & 25.00 & 42 & 6.21 & 2650 & 14.15 & 354 & 16.22 & 162 & 6.59 \\
\hline Balrampur & 3 & 10.00 & 1 & 8.33 & 13 & 1.92 & 2425 & 12.95 & 135 & 6.19 & 54 & 2.20 \\
\hline Total & 7 & 23.33 & 4 & 33.33 & 55 & 8.14 & 5075 & 27.10 & 489 & 22.41 & 216 & 8.78 \\
\hline
\end{tabular}

Source: Directory of industries, 2014 
In Bahraich district, total 3498 persons were engaged in sugar industry, in which 3020 persons in sugar mills, 315 persons in distilleries and 163 persons in small scale sugar units. First sugar mill of this cluster was 'IPL Sugar and Chemicals, established at Jarwal road in 1933 followed by 'Shrawasti Kisan Sahkari Chini Mills Limited', Nanpara (1983), 'Simbhaoli Sugar Limited', Chilwaria and 'Parley Biscuit Pvt. Ltd. ', Kaisarganj. Two distilleries are also working in this cluster, first, chemical division of Shrawasti Kisan Sahkari Chini Mills Ltd., Nanpara (1986) and, second, distillery division of Simbhaoli Sugar limited, Chilwaria (2006).

Basti-Khalilabad cluster: This cluster is situated on the bank of Ghaghra river and includes the centres like Basti, Walterganj, Rudauli and Khalilabad etc which distributed in Basti and Sant Kabir Nagar districts (Figure 4). Except Rudauli, all centres are developed before independence. This cluster registered 13.33 percent of total units and 9.32 percent of total employment of sugar mills, 8.33 percent of units and 3.21 percent of employment of total distilleries and 7.54 percent of units and 6.71 percent employment of total small units (Table 5) in 2012. Basti had 3 sugar mills (10 percent), 1 distilleries (8.33 percent) and 51 small scale sugar units (7.54 percent) while Sant Kabir Nagar (Khalilabad) has only one sugar mill. Basti district, total 1540 persons engaged in sugar industry, in which 1305 persons in sugar mills (6.97 percent), 70 persons in distilleries (3.21 percent) and 165 persons in small scale sugar units (6.71 percent). First sugar mill of this cluster is 'Basti Sugar Company' established at Basti district headquarter in 1927 followed by Govind Nagar Sugar Co. Ltd. Walterganj (1928), Khalilabad Sugar mills Pvt. Ltd., Khalilabad (1943), and The Bajaj Hindusthan Sugar Industries Ltd., Rudauli (2006). A distillery unit was also working under Bajaj Hindusthan Sugar Industries Ltd.; Rudauli (2006) while a sugar mill of U.P. State Sugar Corporation limited (1933) is closed since 1999.

Gonda-Balrampur cluster: This cluster is located in the northern portion of eastern Uttar Pradesh and includes Babhnan, Saidwapur, Mankapur, Maizapur, Balrampur, Utraula and Tulsipur centres (Figure 4). It accounted 23.33 percent of total units and 27.10 percent of total employment of sugar mills, 33.33 percent of units and 22.41 percent of employment of total distilleries and 8.14 percent of units and 8.78 percent employment of total small units (Table 5) in 2012. Gonda had 4 sugar mills (13.33 percent), 3 distilleries ( 25 percent) and 42 small scale sugar units (6.21 percent) followed by Balrampur has 3 sugar mills (10 percent), 1 distillery ( 8.33 percent) and 13 small scale sugar units (1.92 percent) (Table 5). Total 3166 persons were engaged in sugar industry in Gonda district in which 2650 persons in sugar mills (14.15 percent), 354 persons in distilleries (16.22 percent) and 162 persons in small scale sugar units (6.59 percent) while Balrampur district had total 2614 workers (2425 in sugar mills, 135 in distillery and 54 in small 
scale sugar units. Two sugar mills of this cluster were established in 1932, first, is 'Balrampur Chini Mills Ltd.' established at Balrampur district headquarter and, second, Babhnan Sugar company at Babhnan (now Balrampur Chini Mills Ltd. (Babhnan Unit), followed by Tulsipur Sugar Company limited, Tulsipur (1936), Mankapur Chini Mills Ltd., Datauli (2004), Indo-Gulf Industries Ltd.', Maizapur (2005), Bajaj Hindusthan Sugar Industries Ltd., Itaimaida (2006) and Kundurakhi (2007). Besides, distilleries are also working under Balrampur Chini mills Ltd. at Balrampur (1994), Babhnan (2002), Mankapur (2004) and a distilleries unit of Narang Industries limited (1993) while a sugar mill of U.P. State Sugar Corporation limited (1932) is closed since 1998-99.

\section{Centres of sugar industry}

Masaudha (Faizabad), Mijhaura (Ambedkarnagar), Sultanpur, Ghosi (Mau) and Rasra (Ballia) are the major centres of sugar industry in Ganga-Ghaghra doab. Details of these centres are given below:

Masaudha (Faizabad): Masaudha is a town nearer to Faizabad city. This centre has a sugar mill and a distillery, which employed 621 and 70 persons respectively (Table 6) in 2012. This sugar mill (KM Sugar Mills Ltd.) was established in 1942 by Jhunjhunwala family with a distillery of the same name. This mill is single sugar factory of Faizabad district and has a large command area of sugarcane in Faizabad and some part of Sultanpur district. Besides, 17 small scale sugar units (2.51 percent) were also working in the district that provides employment of 70 persons ( 2.85 percent).

Table 6: Structure of industrial centres

\begin{tabular}{|c|c|c|c|c|c|c|c|c|c|c|c|c|}
\hline \multirow{2}{*}{ Districts } & \multicolumn{6}{|c|}{$\begin{array}{l}\text { No. of units and its percentage of } \\
\text { total units }\end{array}$} & \multicolumn{6}{|c|}{$\begin{array}{c}\text { Employment and its percentage of } \\
\text { total employment }\end{array}$} \\
\hline & $\begin{array}{c}\text { Sugar } \\
\text { mills }\end{array}$ & $\begin{array}{l}\text { Per } \\
\text { cent }\end{array}$ & $\begin{array}{l}\text { Disti- } \\
\text { llery }\end{array}$ & $\begin{array}{l}\text { Per } \\
\text { cent }\end{array}$ & $\begin{array}{c}\text { Small } \\
\text { scale }\end{array}$ & $\begin{array}{l}\text { Per } \\
\text { cent }\end{array}$ & $\begin{array}{l}\text { Sugar } \\
\text { mills }\end{array}$ & $\begin{array}{l}\text { Per } \\
\text { cent }\end{array}$ & \begin{tabular}{c|} 
Disti- \\
llery
\end{tabular} & $\begin{array}{l}\text { Per } \\
\text { cent }\end{array}$ & $\begin{array}{c}\text { Small } \\
\text { scale }\end{array}$ & $\begin{array}{l}\text { Per } \\
\text { cent }\end{array}$ \\
\hline $\begin{array}{l}\text { Masaudha } \\
\text { (Faizabad) }\end{array}$ & 1 & 3.33 & 1 & 8.33 & 17 & 2.51 & 621 & 3.32 & 70 & 3.21 & 70 & 2.85 \\
\hline (Mijhaura) & 1 & 3.33 & 0 & 0 & 59 & 8.73 & 1000 & 5.34 & 0 & 0.00 & 223 & 9.07 \\
\hline $\begin{array}{l}\text { Ghosi } \\
\text { (Mau) }\end{array}$ & 1 & 3.33 & 1 & 8.33 & 14 & 2.07 & 802 & 4.28 & 127 & 5.82 & 45 & 1.83 \\
\hline $\begin{array}{l}\text { Rasra } \\
\text { (Ballia) }\end{array}$ & 1 & 3.33 & 0 & 0 & 24 & 3.55 & 503 & 2.69 & 0 & 0.00 & 88 & 3.58 \\
\hline Sultanpur & 1 & 3.33 & 0 & 0 & 7 & 1.04 & 523 & 2.79 & 0 & 0.00 & 18 & 0.73 \\
\hline Total & 5 & 16.67 & 2 & 16.67 & 121 & 17.90 & 3449 & 18.42 & 197 & 9.03 & 444 & 18.05 \\
\hline
\end{tabular}

Source: Directory of industries, 2014 
Mijhaura (Ambedkarnagar): This centre developed into rural area in Ambedkarnagar district. This centre had a sugar mill, namely, Akbarpur Chini Mills (a unit of Balrampur Chini Mills Ltd.) which was established in 2006; employing 1000 persons. Before establishment of this factory, sugarcane cultivation was not a profitable for the farmers of this area. This mill had sugarcane command area in Ambedkarnagar and Faizabad districts. Besides, 59 small scale sugar units ( 8.73 percent) were also existed and provided employment to 223 persons.

Ghosi (Mau): This centre had a unit of Kisan Sahkari Chini Mills Ltd; established in 1984 and employed 802 persons. This mill was single sugar factory of the district and had a large sugarcane command area in Mau, Ghazipur and Azamgarh districts and a distillery of this mill was also working with 127 workers (5.82 percent). Besides, 14 small scale sugar units (2.07 percent) were working in rural areas of this centre and provided employment to 45 persons. A distillery of 'Nibi Steel Limited' (1995) was facing the problem of sickness since 2010-11.

Rasra (Ballia): This centre developed nearer to Rasra town in Ballia district as a unit of Kisan Sahkari Chini Mills Ltd.; established in 1969 that provided employment to 503 persons (2.69 percent). Before establishment of this factory, sugar industry was much developed as small and cottage based in rural areas. Besides, 24 small scale sugar units (3.55 percent) were also working and provided employment to 88 persons.

Sultanpur: This centre had a unit of Kisan Sahkari Chini Mills Limited which was established in 1984 near district headquarter that employed to 523 persons (2.79 percent). Before establishment of this factory, sugarcane formers were sold their cane to Masaudha sugar mill. However, sugar industry was developed as cottage based industry in rural areas in the district since ancient period. Besides, 07 small scale sugar units (1.04 percent) were working and providing employment to 18 persons.

Besides, many other small centres of sugar industry are also located in the study area, like, Ghazipur had a distillery unit namely, 'Lords Distillery' established at Nandganj in 1974 near of 'Nandganj Sihori Kisan Sahkari Chini Mills Limited (closed since 1998) and provided employment to 90 persons where as 8 small scale sugar units were also working and provided employment to 28 persons. Varanasi (14 small scale units with 46 employees), Siddharthnagar (6 small scale units with 52 employees), Shrawasti (5 small scale units with 16 employees), Azamgarh (5 small scale units with 30 employees), Jaunpur (3 small scale units with 9 employees), Kaushambi (3 small scale units with 12 employees) were other centres while Mirzapur and Allahabad has 1 small scale unit each. 


\section{Conclusion}

Sugar industry of the study area was developed mostly during inter world war period because during that period sugar demand was increased in Britain and railway transport was developed by the British government. Many sugar factories, established before plan period, were setup near railway stations. Development of sugar industry took place after 1980s due to favourable government policies. Distribution of sugar industry shows that some districts are more developed due to availability of sugarcane production. Sugar industries are exclusively developed in the areas of intensive sugarcane cultivation especially in the districts of Saryupar plain and Tarai region, like, Kushinagar, Bahraich, Balrampur, Gonda, Basti, Mahrajganj, Deoria and Gorakhpur. These districts have 25 mills out of total 30 mills and make some clusters.

\section{References}

Birru, E. (2016). Sugar cane industry overview and energy efficiency considerations. Department of Energy Technology, Division of Heat and Power Technology, Stockholm, p. 3.

Census of India (2011). Provisional population totals. Ministry of Home Affairs, New Delhi, India. http://www.censusindia.gov.in/Census2011UttarPradeshPaper1. pdf, Accessed on: 16.03.2019.

DoI (2014). Directory of industries. Directorate of Industries of Uttar Pradesh (Planning and Cordination Section), G.T. Road, Kanpur.

DoI (2014). Pragati samiksha. Directorate of Industries of Uttar Pradesh (Planning and Cordination Section), G.T. Road, Kanpur.

Duenas, R., Morales, A., Nannig, C., Noriega, S. and Ortiz, J. P. (2007). Microeconomics of competitiveness the sugar cane cluster in Colombia. Report Submitted in Harvard Business School Boston, Massachusetts, USA, P. 26.

Mathur, P. and Kalia, S. (2005). Fundamentals of industrial geography. Jaipur: Ritu Publications, p. 85.

Pandey, R. K. (2000). Problems and prospects of agro based industries in eastern Uttar Pradesh. (Ph.D. thesis), D. D. U. Gorakhpur University - Gorakhpur, p. 335.

Porter, M. E. (1998). On competition. Harvard Business School, Boston.

Ren, D., Wen, E. And Ren, C. (2014). Theory and method of flower industrial cluster in China. International Conference on Humanity and Social Science (ICHSS), available at: https://books.google.co.in, accessed on 16.03.2019. 
Singh, J. and Ray, J. P. (1975). Impact of sugar industry in the space economy of U.P. Uttar Bharat Bhugol Patrika, Gorakhpur, Vol. XI, June, p. 4.

Singh, R. (2015). Production and growth of sugar industry in Uttar Pradesh. International Journal of Engineering Research \& Management Technology, Volume 2, Issue-1, pp. 56-60.

Sorvik, J. (2008). Clustering and upgrading - A case study of the sugar industries in Brazil and Cuba. Paper presented at Globelics 6th International Conference 2008, available at: https://www.researchgate.net, accessed on 16.03.2019.

Statistical Diary (2015). Sankhyakiya diary Uttar Pradesh. Department of Economics and Statistics, State Planning Institute, Planning Division, Uttar Pradesh. Available at: http://updes.up.nic.in/spiderreports, accessed on 10.10.2018.

Tiwari, A. K. (2014). Development and prospects of sugar industry in eastern Uttar Pradesh. Ph.D. Thesis, Department of Geography, Banaras Hindu University.

Tiwari, A. K. (2017). Indian sugar industry: Development, sickness and environmental problems. New Delhi: R K Books.

Tiwari, A. K. and Sharma, V. N. (2013). Regional variation in development of sugar industry in eastern Uttar Pradesh. Goa Geographer, Vol. X (1), December 2014, pp. 52-60. 